\title{
The Democratic Conference and the Pre-Parliament in Russia, 1917: Class, Nationality, and the Building of a Postimperial Community
}

\author{
Ivan Sablin (11) \\ Department of History, Heidelberg University, Germany \\ Email: ivan.sablin@zegk.uni-heidelberg.de
}

\begin{abstract}
The article offers a detailed analysis of the debates at the All-Russian Democratic Conference and in the Provisional Council of the Russian Republic (the Pre-Parliament), which followed the proclamation of the republic on September 1, 1917, and predated the Bolshevik-led insurgency on October 25. The two assemblies were supposed to help resolve the multilayered political, economic, and military crises of the First World War and the Revolution by consolidating a Russian postimperial political community and establishing a solid government. The debates demonstrated that grievances and antagonism, which were articulated in terms of class and nationality, made the idea of a broad nationalist coalition unpopular, since it would halt agrarian and other reforms and continue the negligence of non-Russian groups. Furthermore, those who still called for all-Russian national or civic unity split on the issue of community-building. The top-down, homogenizing and bottom-up, composite approaches proved irreconcilable and precluded a compromise between non-socialist and moderate socialist groups. The two assemblies hence failed to ensure a peaceful continuation of the postimperial transformation and did not lead to a broad coalition against right and left radicalism. The divisions, which were articulated in the two assemblies, translated into the main rifts of the Russian Civil War.
\end{abstract}

Keywords: Russian Revolution; empire; socialism; nationalism; class; nationality

\section{Introduction}

The First World War and the Russian Revolution brought about major economic and public security crises, which aggravated over the course of 1917 . The summer proved especially disastrous. The Russian offensive failed, and in late August the German Army took Riga and was rumored to be moving to Petrograd (Engelstein 2018, 179). The right were calling for a military dictatorship, which translated into the Kornilov Affair, the suppressed coup attempt of Commander-in-Chief General Lavr Georgievich Kornilov, whose exact plans remain unclear. The radical left continued to campaign for a soviet ("council"), that is class-based, government. Finnish, as well as some Lithuanian and Armenian politicians advocated independence. Although Kornilov was arrested, and the moderate socialist Aleksandr Fedorovich Kerenskii not only retained his position as Minister-President but seemingly strengthened his personal rule, it was the Bolshevik Party (formerly a faction of the Russian Social Democratic Labor Party), which came out as the true victor. By the fall of 1917, the public moods had shifted from the initial revolutionary euphoria to anxiety, and the Bolshevik promises of ensuring provisions, transferring land to peasants, giving

(C) The Author(s), 2021. Published by Cambridge University Press on behalf of the Association for the Study of Nationalities. This is an Open Access article, distributed under the terms of the Creative Commons Attribution licence (https://creativecommons.org/licenses/by/4.0/), which permits unrestricted re-use, distribution, and reproduction in any medium, provided the original work is properly cited. 
workers control of production, and finishing the war gave them majorities in many soviets of workers' and soldiers' deputies, including those in Moscow and Petrograd (Smith 2017, 146-47).

The immediate step of the Provisional Government, which was aided by the soviets during the Kornilov Affair, was the proclamation of the Russian Republic on September 1, 1917. The Provisional Government had been haunted by its own lack of legitimacy and authority since the collapse of the Tsarist government in March 1917. Some of its members and other contemporaries noted the absence of the Tsar's formal sanction of the new authority, the lack of support from below, and the strength of the soviets, particularly in the Army. Although initially the Provisional Government partially relied on the imperial State Duma, it did not allow the resumption of its session in April 1917, considering it an integral part of the old regime and fearing the protests of the soviets and their supporters (Demin 1996, 83). Instead, the Provisional Government sought to gain legitimacy from political pluralism, relying on coalitions between moderate socialists, liberals, and representatives of business elites.

Following the July Days (July 3-5, 1917), the armed anti-government demonstrations organized by radical socialists, Kerenskii headed the Provisional Government. Under his leadership, the Provisional Government organized the State Conference in Moscow (August 12-15, 1917), which included nominees from different organizations, institutions, and interest groups. The Conference was the first attempt to boost the Provisional Government's legitimacy through a quasi-parliamentary assembly, but it did not acquire any formal status. The All-Russian Democratic Conference (September 14-22, 1917), which was organized independently from Kerenskii, and the Provisional Council of the Russian Republic or the Pre-Parliament (October 7-25, 1917) were two further attempts to mend the crises through a socialist or broader public consensus in a provisional parliamentary body. They were supposed to provide the Provisional Government with legitimacy and counteract the possible transition of authority to the soviets ahead of the elections to the Constituent Assembly on November 12, 1917. The Pre-Parliament was also supposed to boost a new coalition between moderate socialists, liberals, and business elites (Startsev 1982; Thatcher 2014, 3-4, 15).

The Democratic Conference and the Provisional Council failed to become proper parliaments. Although each of the two was supposed to be locum tenens for the anticipated Constituent Assembly, they were not formed through universal elections. Instead, they continued to rely on the logic of the "imperial rights regime," based on the "state's assignment of rights and duties to differentiated collectivities," and included nominees from different organizations. In this respect, the two assemblies continued to support differentiated citizenship, representing institutions, interest groups, and legally defined collectivities, despite the persistence of the slogans of "uniform, individual, and equal rights" (Burbank 2006, 400). Notwithstanding this heterogeneous representation, the attempts to build a composite postimperial community, inclusive of different social groups, failed, and the crisis of postimperial sovereignty remained unresolved in both institutional and discursive terms (Gerasimov 2017). The approaches, centred on class and nation, did not necessarily mean homogenization of the political community, based on either of the two categories, but no coherent project of inclusionary community-building emerged. Furthermore, the interparty disagreements overshadowed the supposed shared interests within the many constituent groups of the two assemblies, undermining thereby the very idea of the "imperial rights regime."

The Democratic Conference, which was convened in the aftermath of the Kornilov Affair, was supposed to give the "democracy" (demokratiia), which at the time was used as an umbrella term for socialist parties and groups, revolutionary organizations, and non-propertied classes in general (Kolonitskii 1998), ${ }^{1}$ a leading role in postimperial state- and community-building. Despite being called a "revolutionary parliament," 2 the Democratic Conference had no formal status. Its composition through irregular nomination by a variety of organizations with different status rather than universal elections drew criticism of its legitimacy. Finally, the unclear and ostensibly violated procedure undermined it even further. The Democratic Conference still attempted to establish a 
parliamentary body to which the Provisional Government would be accountable, but the Provisional Government did not agree to it. Instead, the latter created a merely consultative assembly, which included nominees from the constituent groups and parties of the Democratic Conference and the representatives of non-socialist ${ }^{3}$ parties and groups. The explicit use of parties as constituent groups for the Pre-Parliament made the issue of its legitimacy even more problematic and further deepened the political splits. The convocation of the Pre-Parliament shortly before the elections to the Constituent Assembly prompted its participants to use it for campaigning and attempting to reach the population outside the body, which made it comparable to the First and Second State Duma in its radicalism (Usmanova 2014) and granted it many features of a political rally. Only pluralism and open dissensus made the Democratic Conference and the Provisional Council similar to parliaments (Ihalainen, Ilie, and Palonen 2016).

Despite their hybrid, corporatist composition, which reflected the imperial politics of difference and seemed to honor the empire as a composite space with a variety of overlapping group interests, continuing the experience of the State Duma (Semyonov 2009), the particularistic approaches to postimperial community-building predominated. The understanding of nations and classes as "stable collective entities pursuing common political goals" prevailed over the attempts to de-essentialize and use them as building blocks for a composite community (Gerasimov 2017, 36-38). The exclusionary class-based approach of the radical socialists entered mainstream politics, while the lack of attention to the grievances and programs, formulated in terms of nationality, prompted non-Russian activists speak of dissatisfaction with the "Russian (Muscovite) democracy." 4 The homogenizing, Russian-centric ${ }^{5}$ approach of non-socialist politicians was unacceptable to those who defined themselves through class and nationality.

The discourse of building a composite Russian community, which could suit the imperial and postimperial complexity and had been the oppositional mainstream during the imperial transformation since 1905, was still there. Unlike other "imperial nationalisms" (Berger and Miller 2015, 4-5), it did not imply total assimilation, since the Russian community was to remain internally diverse. Among its variations and ambiguities (Brubaker 1998), the idea of retaining the shared imperial space was central. The First World War amplified the statist component of this imperial patriotism but also gave prominence to its aspirational, progressive component which stressed the need of ensuring a better future rather than that of merely keeping the integrity of the imperial space (Stockdale 2016, 10-11). The aspirational component was further emphasized during the Revolution. The discourse of revolutionary defencism, however, shifted to the background due to the political practices of its proponents and the rise of the particularistic alternatives by the time of the two assemblies.

With the exception of two Russian-language monographs by Svetlana Evgen'evna Rudneva (2000; 2006), which mainly reproduced the historical sources in a chronological manner, the Democratic Conference and the Pre-Parliament had been subject to little scrutiny within the contexts of the 1917 Revolution and the larger imperial transformation. The brief discussions of the assemblies tended to focus on the relations between a handful of top-tier politicians (Engelstein 2018, 171-84; Smith 2017, 146-47; Wade 2017, 213, 220-21). While some scholars addressed the two assemblies as peculiar corporatist political institutions (Orlovsky 1997), the debates in them were barely analysed. Geoffrey Swain (1996, 5, 44-52), who emphasized the "enormous importance" of the events in the Pre-Parliament for the historians of the Russian Civil War, provided the most detailed discussion in English, but also mainly focused on the relations between the top-tier politicians and the main political groups.

This article reconstructs the debates at the Democratic Conference and in the Pre-Parliament across the whole political spectrum and demonstrates the main points of contestation between political parties and the constituent interest groups, including minor parties and national organizations which were often omitted from the broader historiographic discussions. In particular, it reveals the contrast between the heterogeneous and uneven "imperial" representation at the two assemblies and their failure to come up with a single inclusionary approach to postimperial 
community-building. Furthermore, it demonstrates the flexibility of class and nationality slogans, which were used by political opponents, and argues that the articulation of class and nationality difference, which often intersected (Suny 1993), did not necessarily lead to exclusionary community-building.

This study relied on the complete summaries and partial verbatim reports, as well as other documents of the two assemblies. The proceedings were partly available in the State Archive of the Russian Federation (GARF), while the missing parts were discovered in the newspapers of the period. The newspapers of different political orientation also provided extensive commentary and were used for reconstructing the multiperspective political context of the debates. This article relied on the newspaper Rech' (Petrograd) of the Constitutional Democratic (KD) Party; Delo naroda (Petrograd) of the Party of Socialists-Revolutionaries (SR); Sotsial-demokrat (Moscow) of the Bolshevik Party; Vpered! (Moscow) of the Menshevik Party; ${ }^{6}$ Narodnoe slovo (Petrograd) of the Toiling People's Socialist Party; Edinstvo (Petrograd) of Grigorii Valentinovich Plekhanov right socialist Unity Group; the non-partisan liberal Sovremennoe slovo (Petrograd) and Russkie vedomosti (Moscow); the right Vechernee vremia (Petrograd); the anarchist Anarkhiia (Moscow), as well as the gazette of the Provisional Government Vestnik Vremennogo pravitel'stva (Petrograd). The brief review of several Russian-language periodicals, published outside the country's two largest cities (in Baku, Kyiv, Minsk, Pskov, Tomsk, Vladivostok, and Vologda), demonstrated that commentary on the three assemblies there was rare and similar to that in the centrally published newspapers. Several moderate socialist periodicals, Vol'naia Belarus' (Minsk), Vil'na Ukraina (Uman), and Izvestiia Soveta rabochikh i soldatskikh deputatov gor. Tiflisa (Tiflis), however, allowed to get a glimpse of peculiar non-Russian national and regional perspectives on the three assemblies.

\section{Overview}

In the context of military, economic, and political crises, moderate socialist parties attempted to create a representative body, which would strengthen the left orientation of the Provisional Government and ensure a public consensus for the defencist war effort. Both the Democratic Conference and the Pre-Parliament were made up of nominated delegates from different organizations, following the imperial logic of political representation, and their composition was contested. Neither of the two became a parliament, and the Provisional Government remained formally unaccountable.

In August 1917 Russian socialists assembled for a conference on defense, which resulted in a split between the Bolsheviks, who rejected the continuation of the war, and moderate socialists. The same month the State Conference revealed another rift between moderate socialist and nonsocialist politicians on how the war effort was to be boosted. Although only some non-socialist politicians were implicated in the Kornilov Affair in late August, many socialists blamed all of the "bourgeoisie." Members of the All-Russian Central Executive Committee of Soviets of Workers' and Soldiers' Deputies (VTsIK) articulated the idea of a "provisional national assembly" to which the Provisional Government would be accountable. On August 27-28, a joint meeting of the VTsIK and the Executive Committee of the All-Russian Soviet of Peasants' Deputies ${ }^{7}$ resolved to appeal to the Provisional Government to call a conference, similar to the one in Moscow but consisting only of "democratic" elements (Rudneva 2000, 34, 40-41).

The Provisional Government did not support this suggestion, but the two executive committees still convened the All-Russian Democratic Conference, or the "All-Russian Conference of Democratic Organizations." Its core was to be made up of the "democratic" organizations, which participated in the Moscow State Conference, but the proportions were changed. The Democratic Conference had 1,582 seats and relied on heterogeneous and uneven group representation. Most seats were allocated to municipal self-government bodies (300); zemstvo self-government bodies (200); workers' and soldiers' soviets (230); peasants' soviets (230); the Army and the Navy (125); "allestate" cooperation $^{9}$ (120); workers' cooperation (38); trade unions (100); and Cossack 
organizations (35). Whereas the municipal bodies had already been re-elected universally, the elections to zemstvos were still underway, and their delegations included both the prerevolutionary non-socialists politicians, and the co-opted socialists. Ukrainian, Lithuanian, Belarusian, Armenian, Jewish, Latvian, Polish, Muslim, and other non-Russian organizations received a total of 60 seats. Most of the remaining seats were allocated to the specialized bodies of the Provisional Government and individual professional organizations. ${ }^{10}$ The SRs of different factions won 532 seats, the Mensheviks 172 seats, and the Bolsheviks 136 seats; 400 delegates registered as non-partisan (Raikhtsaum 1993a, 383).

The composition of the Conference was contested. Moderate socialist press argued that municipal bodies, formed through universal elections, were underrepresented, and hence the Conference would not have authority for the "broad democracy." Soviet delegates were dissatisfied with the number of seats allocated to the soviets and with the "curial" (that is based on the representation of different legally defined groups, institutions, and organizations) rather than party-based representation. The exclusion of the Council of the Union of Cossack Hosts led to a boycott from some of those Cossack organizations which had been invited. The Bolshevik press denounced the Conference's composition, arguing that the Mensheviks and the SRs created this body because they were losing their positions in the soviets. Commentators and delegates alike did not see the Conference as a competent institution, since it was not convened by the Provisional Government. The Conference was undermined even further when Kerenskii started the talks with non-socialist politicians on a new coalitional cabinet before the Conference opened. The SR Central Committee nevertheless resolved that the Conference was to create a "pre-parliament," to which the Provisional Government would be accountable. ${ }^{11}$

The Democratic Conference opened on September 14 in the Alexandrine Theatre in Petrograd. Members of the Provisional Government, including Kerenskii, attended it, even though it lacked any formal status. The Presidium of the Conference included inter alia the Mensheviks Nikolai Semenovich Chkheidze (the VTsIK Chairman), Iraklii Georgievich Tsereteli, Fedor Il'ich Dan (Gurvich); the SRs Nikolai Dmitrievich Avksent'ev (the Chairman of the Executive Committee of the All-Russian Soviet of Peasants' Deputies and the former Minister of Internal Affairs), Viktor Mikhailovich Chernov, Grigorii Il'ich Shreider (Petrograd Mayor), and Vadim Viktorovich Rudnev (Moscow Mayor); and the Bolshevik Lev Borisovich Kamenev (figures 1 and 2).

The debates predominately consisted of statements by different constituent groups and political parties, which made the Conference similar to a political rally. The most debated issue was the choice between a coalitional and a "uniform" socialist (or "democratic") government. Most speakers supported the accountability of the Provisional Government to a pre-parliament. The first vote on coalition on September 19 proved inconclusive. The issue split each "curial" group. A slight plurality of 766 votes to 688 and 38 abstaining supported a coalition. The delegates of soviets

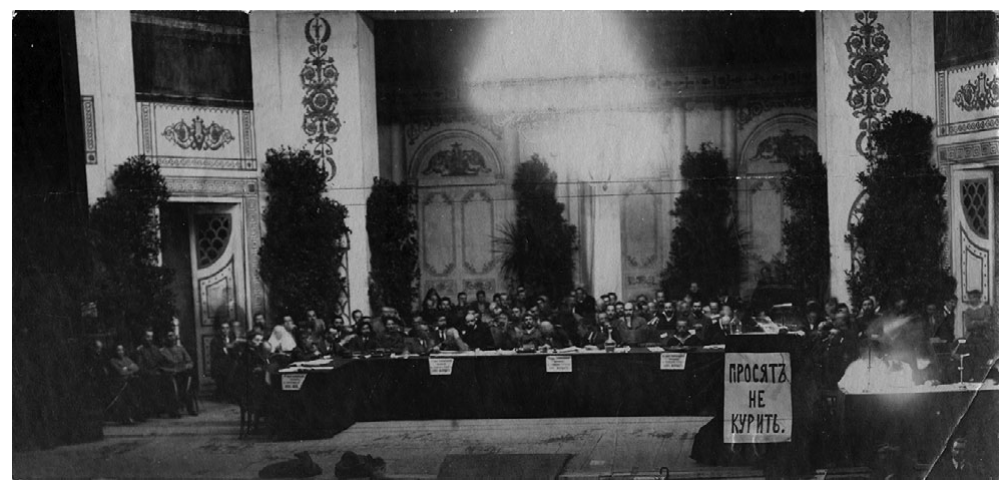

Figure 1. Presidium of the All-Russian Democratic Conference, Petrograd, September 1917. GTsMSIR, 6095/173. 


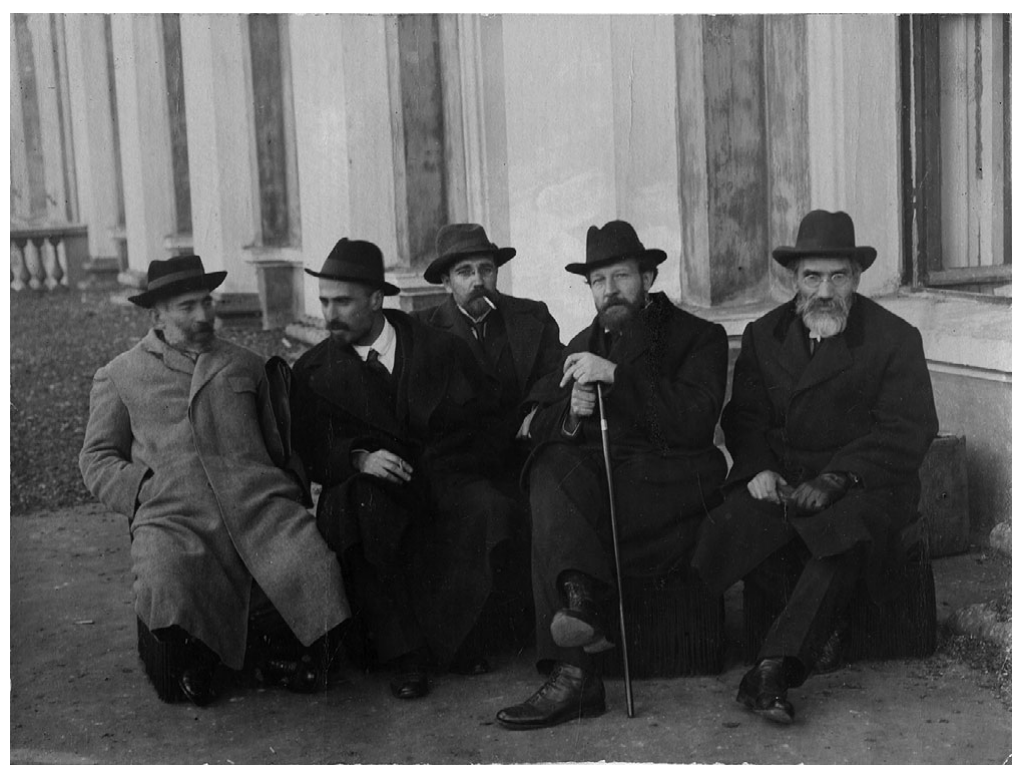

Figure 2. Members of the Presidium of the All-Russian Democratic Conference, Petrograd, September 1917. Photo by P. A. Otsup. Left to right: N. S. Chkheidze, I. G. Tsereteli, L. B. Kamenev, N. D. Avksent'ev, and G. I. Shreider. GTsMSIR, $11880 / 232$.

of workers' and soldiers' deputies and trade unions were predominantly against a coalition; those of cooperatives and zemstvos were predominately in favor. Peasant soviet, military, and municipal groups split almost evenly. Yet most delegates rejected those who were implicated in the Kornilov Affair and the KD Party as a whole as possible coalition partners in two subsequent votes. After this, the issue of coalition was again put to vote and rejected with 813 votes to 183 and 80 abstaining. The Conference, however, did not resolve to form a "uniform" socialist government either. Instead, the Presidium proposed discussing the issue in a smaller meeting of representatives of all "curial" groups and political "currents," which the Conference approved. ${ }^{12}$

The smaller meeting put the issue of coalition aside and agreed on nominating a pre-parliament from "curial" groups and political parties, to which the Provisional Government would be accountable. Kerenskii, who was present at the meeting, did not object to a pre-parliament but only if such a body represented the nation as a whole. Kamenev reaffirmed that his party would support only a soviet government or a "democratic" government. Tsereteli drafted the compromise resolution and presented it at the plenary on September 20. He left the issue of including nonsocialists in the pre-parliament open, and the Bolshevik Lev Davidovich Trotskii and the left SR Vladimir Aleksandrovich Karelin again rejected the idea of coalition. The individual points of the resolution - on the pre-parliament, representing the whole country and therefore including nonsocialists, and the accountability of the government to it - were adopted with significant majorities. The Bolsheviks argued that the text differed from what was agreed upon at the smaller meeting. Tsereteli's sarcastic remarks on dealing with Bolsheviks led to their protest. The final vote, without the participation of many of the Bolsheviks, adopted the resolution on the pre-parliament, which was to be coalitional but still to have a majority of the "democracy's" representatives, with 829 votes in favor, 106 against, and 69 abstaining. The Bolsheviks recalled its members from the Presidium but did not leave the Conference. Their representatives rebuked the inclusion of non-socialists in the pre-parliament and the Conference itself. ${ }^{13}$

Non-socialist and many socialist commentators criticized the Democratic Conference. Russkie vedomosti deemed it a failure, since it simply delegated the issue of coalition to a new body. It also dismissed the demands of the accountability of the Provisional Government to the pre-parliament, since the Conference had no legal basis. ${ }^{14}$ Plekhanov criticized the idea of the pre-parliament due to 
its legal unclarity and unrepresentative nature and pointed to the negative experience of the German Vorparlament ("pre-parliament") in $1848 .{ }^{15}$ Anarkhiia dismissed the Conference of "state socialists" as useless against counterrevolution and lambasted its "parliamentary trickery." 16

The Democratic Conference established the Democratic Council, which was proportionally elected from the "curial" groups, some of which resolved to distribute their seats between different parties. The issue of the pre-parliament was resolved in the meetings between the Provisional Government, the representatives of the Democratic Conference, of the non-socialist Council of Moscow Conferences of Public Figures, and the KD Central Committee on September 22-24. In these meetings, non-socialists, especially the KDs, opposed the accountability of the government to the pre-parliament with unclear legal basis and questionable composition. Kerenskii also opposed the accountability. Moderate socialists conceded despite the resolution of the Democratic Council ("the All-Russian Council of Democratic Organizations"), which assembled on September 23, in favor of the government's accountability. The Provisional Government announced its own new coalitional composition on September 25. Tsereteli's proposal to call the Pre-Parliament "the Provisional Council of the Russian Republic" was nevertheless supported. ${ }^{17}$

Kerenskii celebrated the Provisional Council as a manifestation of the will of the "majority," albeit imperfect, on which the government could "rely." 18 Rech' expected it to be at the center of public attention and provide the government with a rostrum for defending its policies, but admitted that it could also increase chaos. ${ }^{19}$ Among the Bolsheviks, Kamenev's readiness to participate in the Pre-Parliament was countered by Vladimir Il'ich Lenin. Upon Lenin's return to Petrograd in October, the Bolshevik Central Committee supported his position against the Pre-Parliament and in favor of an armed insurgency (Engelstein 2018, 174-75; Savel'ev and Rakhmetov 1929, 70-71). Anarkhiia dismissed the Pre-Parliament as the "child" of Tsereteli and "compromising" (soglashatel'stvo.$^{20}$

On October 2, the Provisional Government adopted the Regulations on the Provisional Council of the Russian Republic, which was scheduled to open on October 7. The new body had 555 seats, of which 388 were reserved for the "democratic" elements, although the proportion was not part of the Regulations. It could discuss legislative proposals and had the right to interpellation, but the government remained unaccountable. The members of the Provisional Council were granted partial immunity from prosecution. On October 6, the Provisional Government reaffirmed November 12 as the date for the elections to the Constituent Assembly and formally dissolved the imperial State Duma ${ }^{21}$ and the State Council. ${ }^{22}$

The Democratic Council became the core for the 388 seats reserved for the "democracy." The seats of the "non-socialists" were distributed between the KD Party (64 seats), the Trade and Industrial Group (34), the Council of Moscow Conferences of Public Figures (12), the Union of Landowners (7), and other groups, including further Cossack and non-Russian national organizations. The Provisional Council had pluralistic yet unequal and irregular representation, with delegates being nominated by political parties and groups, self-government bodies, and other organizations. In this respect, it was a hybrid of an imperial parliament, with its representation of legally defined groups, and of the anticipated "national" parliament, which was to represent a homogeneous "nation" through political parties. According to incomplete data, there were 135 SRs, 92 Mensheviks, 75 KDs, 58 Bolsheviks, and 30 members of the Labor People's Socialist Party in the Pre-Parliament. ${ }^{23}$

Unlike the State Conference and the Democratic Conference, the Pre-Parliament had more parliamentary features in its internal organization and procedure. Following the German model, the factions agreed to form "the Council of Elders" (Ältestenrat) of different groups and factions (figure 3) (Rudneva 2006, 105).

The Provisional Council opened on October 7 in the Mariinsky Palace in Petrograd, the former seat of the imperial State Council. The imperial coat of arms, one of the most widely destroyed symbols during the Revolution (Kolonitskii 2012, 88-97), and Il'ia Efimovich Repin's paining of the State Council were covered by cloth. The right side was assigned to the "propertied elements" (those who met the property qualifications in the imperial elections), the center to the SRs and the 


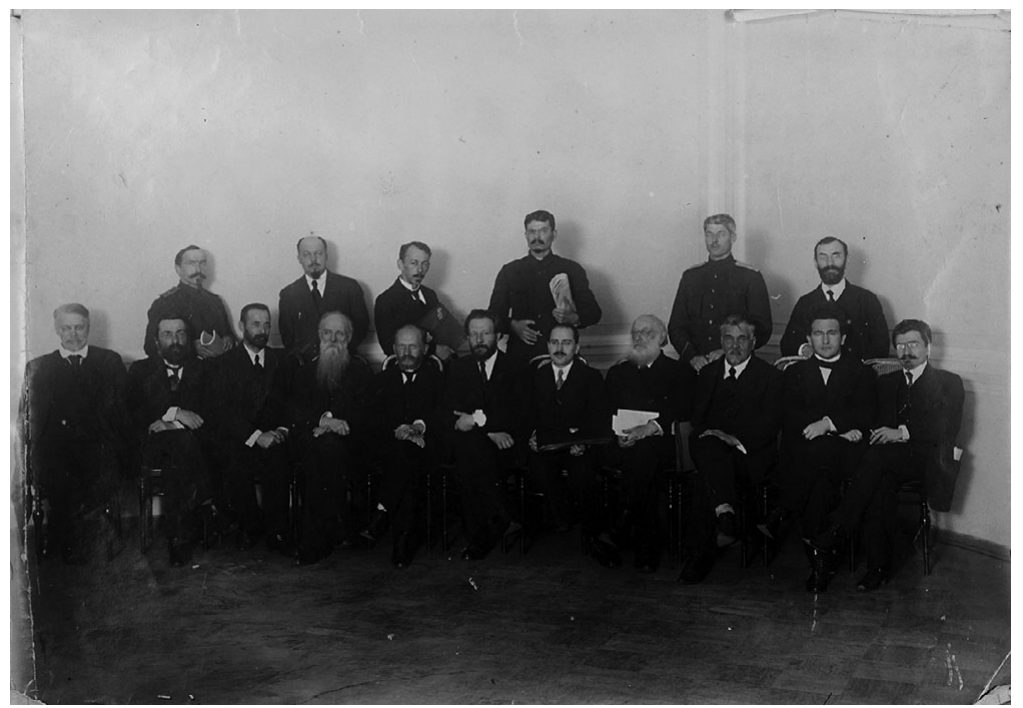

Figure 3. Members of the Council of Elders of the Provisional Council of the Russian Republic, Petrograd, October 1917. Photo by P. A. Otsup. RGAKFD, 4-19708. Front row, left to right: F. I. Rodichev, N. N. Kutler, M. E. Berezin, N. V. Chaikovskii, M. M. Vinaver, N. D. Avksent'ev, M. V. Vishniak, M. A. Natanson, I. N. Sakharov, B. O. Bogdanov, S. L. Vainshtein. Back row: R. A. Abramovich (first from the right); in no particular order: B. D. Samsonov, [V. N.] Ferri, V. S. Sizikov, V. P. Chefranov, E. E. Gorovoi.

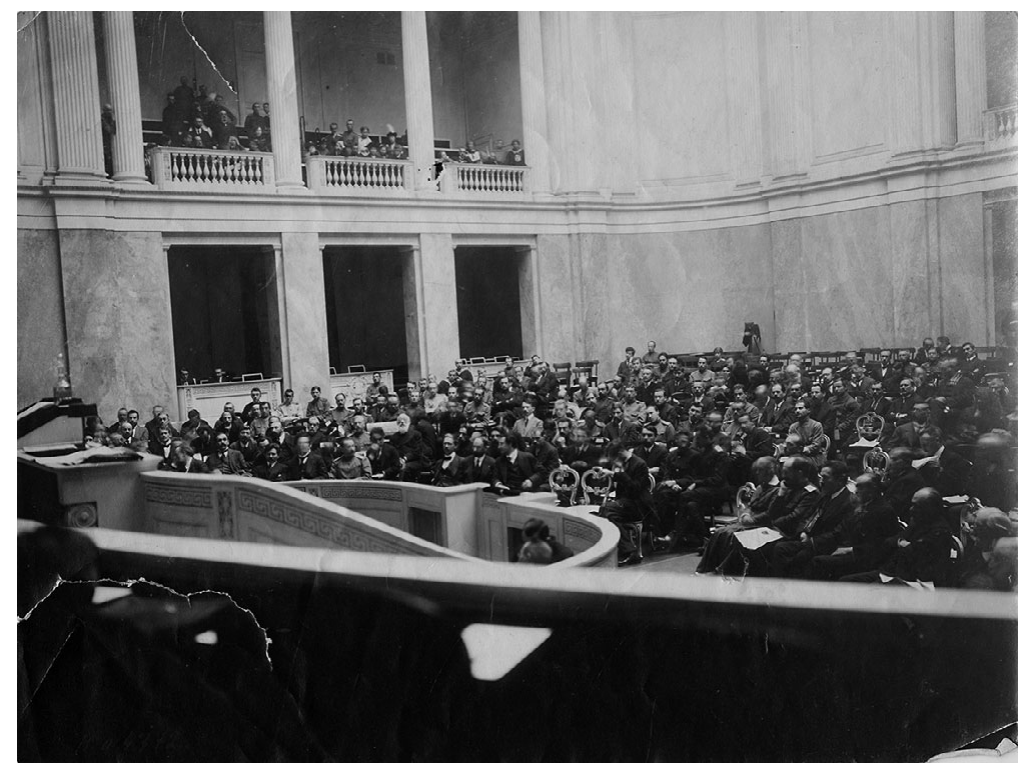

Figure 4. The Provisional Council of the Russian Republic in session, Petrograd, October 7, 1917. GTsMSIR, $4772 / 371$.

Mensheviks, and the left side to the Bolsheviks (figure 4). Kerenskii opened the session when around one third of seats was still empty, and the Bolsheviks entered when he was already speaking. Avksent'ev was elected Chairman of the Presidium. ${ }^{24}$

The highlight of the first day was the protest declaration of the Bolsheviks, read out by Trotskii, and their walkout. The declaration denounced the Pre-Parliament's origins in the "behind-thescenes deals between Kerenskii, the KDs, and the leaders of the SRs and the Mensheviks" and its contradiction to the objectives of the Democratic Conference. It protested the inclusion of those 
who were implicated in the Kornilov Affair and the lack of the government's accountability, comparing the Pre-Parliament to the "Bulygin Duma," the 1905 project of a consultative imperial parliament. Trotskii's speech, directed against the KDs and the government, was frequently interrupted by shouts. The Bolshevik seats were not reassigned to other groups after they had left. ${ }^{25}$

The Pre-Parliament formed several commissions. It had nine plenary meetings, which were mainly devoted to the discussions of defense and foreign policy, following the speeches of War Minister Aleksandr Ivanovich Verkhovskii (figure 5) and Minister of Foreign Affairs Mikhail Ivanovich Tereshchenko, respectively. Kerenskii used the Council as a rostrum for denying the rumors that the Provisional Government intended to surrender Petrograd to the Germans and flee to Moscow. Groups of deputies also posed several formal questions to the government. Plenary sessions and commissions had problems with quorums. The Council also did not have a stable majority. After the discussion of defense, none of the five proposed resolutions was adopted. The discord made commentators and deputies argue that the Pre-Parliament was merely used for campaigning for the elections to the Constituent Assembly. ${ }^{26}$

On October 24, Kerenskii addressed the Pre-Parliament on the issue of the anticipated Bolshevik insurgency and practically asked it to sanction harsh measures against it. Two draft resolutions were put to vote. The draft of the Mensheviks, the (more radical) Mensheviks-Internationalists, the SRs, and the left SRs cautioned against the insurgency, but argued that its reasons were in the lack of reforms. It called the Provisional Government to immediately pass land to the land committees (local bodies which were supposed to prepare the agrarian reform) as the first step in its transfer to peasants and propose peace negotiations to the Allies. The draft of the cooperative organizations and the KDs urged to fight "treason," declared full support for the Provisional Government, and demanded the most extreme measures against the insurgency. The socialist resolution won with 123 votes in favor to 102 against and 26 abstaining. The members of the Provisional Government considered this a vote of no confidence, but Avksent'ev told Kerenskii that this was not the case, and its only purpose was to counter the Bolshevik slogans. On October 25, the Pre-Parliament was supposed to hold its tenth meeting, but before it opened, the Mariinsky Palace was surrounded by the troops of the Bolshevik-led Military Revolutionary Committee. The Council of Elders issued a protest, and the meeting was called off. ${ }^{27}$ The Bolshevik-led coup, which was supported by the left SR put an end to the Provisional Government and the Pre-Parliament.

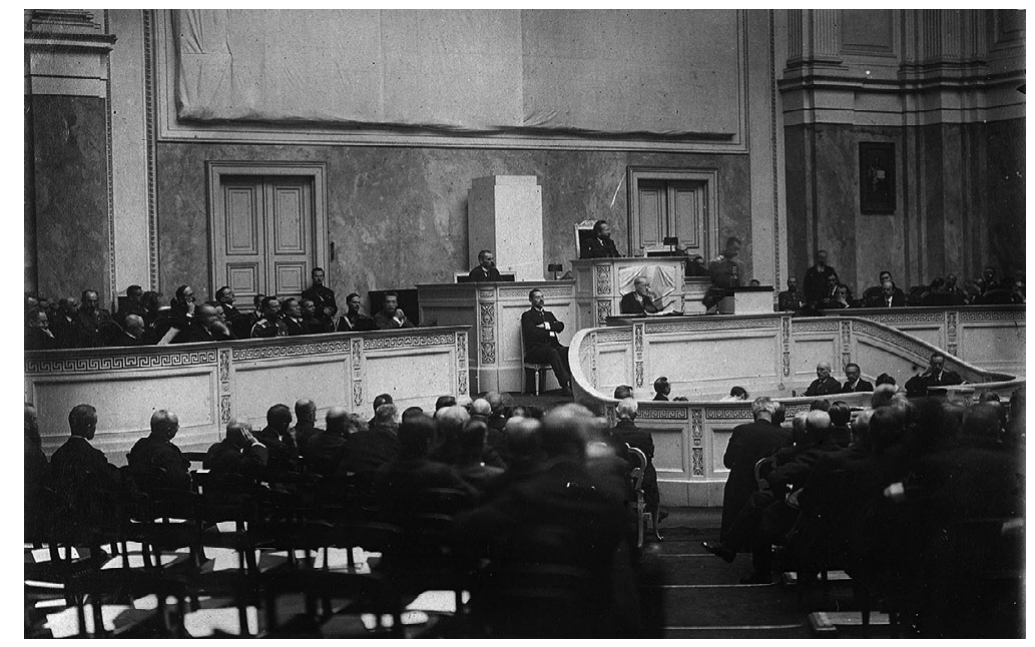

Figure 5. War Minister A. I. Verkhovskii speaking in the Provisional Council of the Russian Republic, October [10], 1917. RGAKFD, 4-19789. N. D. Avksent'ev is chairing; A. F. Kerenskii is seated on the left side first from the right. 


\section{Class}

The debates at the Democratic Conference, in the Pre-Parliament, and in the press included frequent articulations of difference, predominately formulated in terms of class, which was one of the main foundations for an exclusionary approach to postimperial political community. Most supporters of class interests opposed a coalitional government. At the same time, many of them did not necessarily support the Bolsheviks.

Ahead of the Democratic Conference, the Bolsheviks were the main advocates of an exclusionary class-based approach to building a postimperial political community. Speaking at the meeting of the Petrograd Soviet on September 11, 1917, its Chairman Trotskii asserted that the SRs' and the Mensheviks' compromises with the bourgeoisie resulted in the Kornilov Affair. Kamenev then read the Bolshevik resolution opposing any compromises with the "landowner and bourgeois" parties and advocating a government of delegates from workers', peasants', and soldiers' organizations. The program for such a government involved an immediate proposal of a democratic peace to end the First World War; transfer of private land to peasant committees; workers' control in production and distribution; "merciless taxes for large capitalists and other propertied," and confiscation of wartime profits. This resolution won the majority of votes, given the Bolshevik predominance in the Petrograd Soviet. The left SRs and the Mensheviks-Internationalists also opposed a coalition ahead of the Democratic Conference. ${ }^{28}$

At the Democratic Conference, many speakers against coalition cited the irreconcilable class differences. Chernov recalled the divide between "propertied" and "democratic" Russia at the Moscow State Conference and maintained that there could be no agreement on foreign policy and the land question, which had to be resolved immediately in order to prevent anarchy in the countryside. The majority of the trade unions' delegation supported the resolution of the Petrograd Soviet. The workers' cooperatives' representatives also called for a uniform "democratic" authority. A delegate representing sailors advocated a soviet government. The Bolsheviks did not, however, have a single interpretation of a class government. Kamenev interpreted the Democratic Conference as a body of peasants', workers', and soldiers' organizations and prompted it to take power. Vladimir Pavlovich Miliutin, who represented the Bolsheviks in the municipal group, called the August 14 program of the "democracy" at the Moscow State Conference insufficient and advocated the transfer of all authority to the soviets of workers' and soldiers' deputies. Trotskii, who spoke on behalf of the Bolshevik Party, left the issue open but urged the Democratic Conference to appeal to the soviets no matter what government it created. ${ }^{29}$ The core of the disagreement hence pertained to the scope of the exclusion from the class-based community. In practical terms, it also revolved around the issue of a coalition among the socialists.

The Bolshevik press used class terms to criticize other socialists. Grigorii Evseevich Zinov'ev, who was then in hiding, wrote in Rabochii put' that the proponents of the coalition broke with the working class and surrendered to the mercy of imperialists and counterrevolutionaries. According to Zinov'ev, the "treason" of the SRs and the Mensheviks would also alienate soldiers and the vast majority of peasants from them. In another article Zinov'ev claimed that class struggle occurred at the Democratic Conference itself (Zinov'ev 1925, 346, 349-50). The SR press contended that proletariat could not win by going against the "democratic" voice of the country-the broad "democratic" mass from revolutionary peasants to cooperatives. ${ }^{30}$

There was no unified position on the role of the "bourgeoisie," since many Russian Marxists and non-Marxists considered the Russian Revolution a bourgeois revolution. Class rhetoric was hence also used by the opponents of exclusionary class-based community-building. Aleksandr Moiseevich Berkengeim, who spoke on behalf of the Central Committee of Cooperatives, stressed the "bourgeois" character of the Revolution at the Democratic Conference. Plekhanov's Edinstvo opposed the idea of a socialist pre-parliament, asserting that during a "bourgeois revolution" the "bourgeoisie" had to be in charge. Rech' ridiculed the Democratic Conference, citing the futile attempts to create "a strong socialist government in a bourgeois state." Rafail Abramovich 
Abramovich (Rein) of the Jewish Labor Bund claimed that his party did not oppose an agreement with other classes for the "bourgeois" revolution, but suggested that there was no "bourgeois" group which could offer an alternative to the socialist economic, agrarian, and military projects. ${ }^{31}$

Many socialists, however, disagreed that the Russian Revolution was a "bourgeois" revolution. Pavel Liudvigovich Lapinskii (Levenson), a Polish Menshevik-Internationalist, insisted that the depth of the Russian Revolution was unmatched and that the connections between the leaders of the Russian bourgeoisie and the imperialist circles of the Allies made it an international conflict with a deep class meaning. Trotskii argued that the Russian Revolution occurred in the context of developed world capitalism, when there was no bourgeois democracy and when imperialism reigned supreme. According to Trotskii, waiting for the revival of bourgeois democracy was the greatest utopia. A speaker for the majority of provincial committees of peasants' deputies articulated a left SR view when claiming that bourgeoisie was simply not capable of abandoning its class interests. Representatives of non-Russian nationalities of moderate socialist orientation used class rhetoric for defending their national interests. The Ukrainian Social Democrat Nikolai Vladimirovich Porsh (Mykola Volodymyrovych Porsh), who spoke on behalf of the Ukrainian Central Rada, claimed that the lack of recognistion of Ukrainian authorities by the Provisional Government was dictated by "the imperialist aspirations of the Great Russian bourgeoisie." 32

Some opponents of coalition pointed to the center-periphery discrepancies in the class politics. Responding to the debates in Petrograd, Nikolai Iotamovich Kartsivadze, a Georgian Menshevik and a member of the Tiflis Soviet of Workers' and Soldiers' Deputies, claimed that the Petrograd leadership was detached from the "democracy" of all Russia due to the "strong and constant pressure of the bourgeoisie," while in the provinces the front of the "democracy" was united. Rudnev, by contrast, argued that locally the authorities were often coalitional and hence a coalition was needed in the center. ${ }^{33}$

In the Pre-Parliament, it was also socialists who predominantly appealed to class. The right SR Ekaterina Konstantinovna Breshko-Breshkovskaia, who delivered a brief speech at the opening of the Pre-Parliament as its oldest member, urged the new body to resolve the land question according to the wishes of all "peasant Russia" and transfer land to the peasants. The SR declaration called for passing all arable lands to the land committees and for implementing social reforms. The reforms were supposed to reassure soldiers, who were mainly of peasant background, that they fought for the transfer of land to the hands of the "toiling people." The Mensheviks-Internationalists also called for the transfer of land to the land committees, claiming that it was the only way to fight anarchy. The Mensheviks stressed that the interests of workers had to be observed in the case of partial transfer of industries and population from Petrograd, which the government considered. Kerenskii reassured that the affected workers would be provided for. The left SRs initiated a formal question to the government on Cossack violence against the soviet in Kaluga. The MensheviksInternationalists delivered a declaration against the Council, claiming that they were staying in it only because they saw it as "an arena of open class struggle." On October 24, the left SR Kamkov claimed that Bolshevism was on the rise due to the loss of trust in the government by "conscious" elements among the toiling peasants and the proletariat and argued that only a uniform "revolutionary democratic" government could prevent a civil war. ${ }^{34}$

Attacks on the "bourgeoisie" also continued. The Bolshevik declaration, which accompanied their walkout on October 7, accused the "bourgeois classes" or the "propertied elements," which ostensibly steered the policy of the Provisional Government, of plotting against the convocation of the Constituent Assembly. In the economic sphere, the declaration asserted, the policy of the government and the propertied classes worsened the "natural" chaos, caused by the war. It accused these classes of provoking a peasant rebellion, of trying to start a famine, of protracting the war, and of plotting to surrender the "revolutionary capital" to the Germans. The declaration reminded that sailors and soldiers were dying for the mistakes made by others and concluded with an appeal to the vigilance and bravery of workers, soldiers, and peasants of all Russia. The Menshevik-Internationalist Iulii Osipovich Martov continued this line of accusation by insisting that the propertied classes put their class interests 
ahead of the national ones and used the Army as a "class instrument." The Mensheviks-Internationalists also delivered a declaration which accused the propertied elements of prolonging the war and of sabotage which led to disorganization. The Mensheviks-Defencists also accused the propertied classes of protracting the war and pursuing imperialist goals. Dan, one of their leaders, claimed that the war was waged by the "propertied classes" at the expense of the people and that these classes used patriotism for distracting the "democracy" from internal policies. The SR Chernov blamed the "propertied elements" for postponing the fall of the old regime and thereby stimulating the crisis. ${ }^{35}$

Most of those socialists who remained in the Pre-Parliament did not support the Bolsheviks but also did not support their suppression. Dan claimed on October 24 that their anticipated insurgency was not an act of "revolutionary proletariat" and reassured that most of the working class would not follow the Bolsheviks in their "crime" against the Revolution. At the same time, Dan claimed that socialists should not turn into a weapon of the counterrevolution, and if the Bolshevik uprising was violently suppressed, the "democracy" would also be defeated. He again accused the propertied classes of preventing the satisfaction of the needs of popular masses and called for immediate peace negotiations and the transfer of land to the peasants. Martov claimed that the MensheviksInternationalists would not participate in suppressing the insurgency and reaffirmed that only a government of the "democracy" could prevent a civil war. ${ }^{36}$

The non-socialists rarely cited class difference during the debates in and around the PreParlament, but also resorted to accusations against social groups. The KD Moisei Sergeevich Adzhemov, for instance, stressed that the workers rather than the industrialists were to blame for the falling production in the Donetsk Basin. A group of non-socialist deputies also initiated a question to the Provisional Government on the possible strike at textile enterprises and the measures by the authorities to "resume normal order and prosecute the violators." Interestingly, it was Kerenskii who used the derogatory word chern' ("plebs" or "rubble") on October 24 when speaking of the potential backers of the Bolshevik insurgency. ${ }^{37}$

\section{Nationality}

Difference in terms of nationality, which at times intertwined with religion, was mainly articulated by the representatives of non-Russian parties and groups at the Democratic Conference and in the PreParliament. The suggestions to turn Russia into a federation, with nationalities gaining territorial and extraterritorial autonomy predominated, which meant that the articulation of nationality-based difference was mainly used when defending inclusionary community-building. There were, however, also occasional voices in favor of secession and thereby exclusionary nation-building.

The autonomist slogans of different non-Russian political groups consolidated in the State Duma and were amplified during the Revolution of 1917 (Sablin and Semyonov 2020). On September 8-15, 1917, ahead of the Democratic Conference, the Ukrainian Central Rada convened the Congress of Representatives of Peoples and Regions in Kyiv. It united 93 delegates from Jewish, Latvian, Lithuanian, Ukrainian, Polish, Belarusian, Estonian, Georgian, Romanian, Muslim, Cossack, and other organizations which supported a federative reconstruction of Russia. The Congress called for an immediate proclamation of a federative republic to be based on the principle of nationality, while dispersed groups were to receive extraterritorial (personal) autonomy. It also adopted several resolutions on individual groups and issues. The resolution on the Cossacks recognized them "as an independent branch of the peoples of the Russian Republic," treating thereby this social estate as a nationality. The resolution on languages proposed retaining Russian as the federal language but demanded equality for all other languages and allowed the "states" (shtaty) of the federation to have one or multiple official languages. The Congress also called for the reorganization of the Army on the principle of nationality. It demanded that full self-determination rights for all nations were the main principle of the future peace talks, while the representatives of all Russia's nationalities were to participate in them. The Congress also called for the establishment of the "Council of Nationalities" under the Provisional Government, which the latter in fact had 


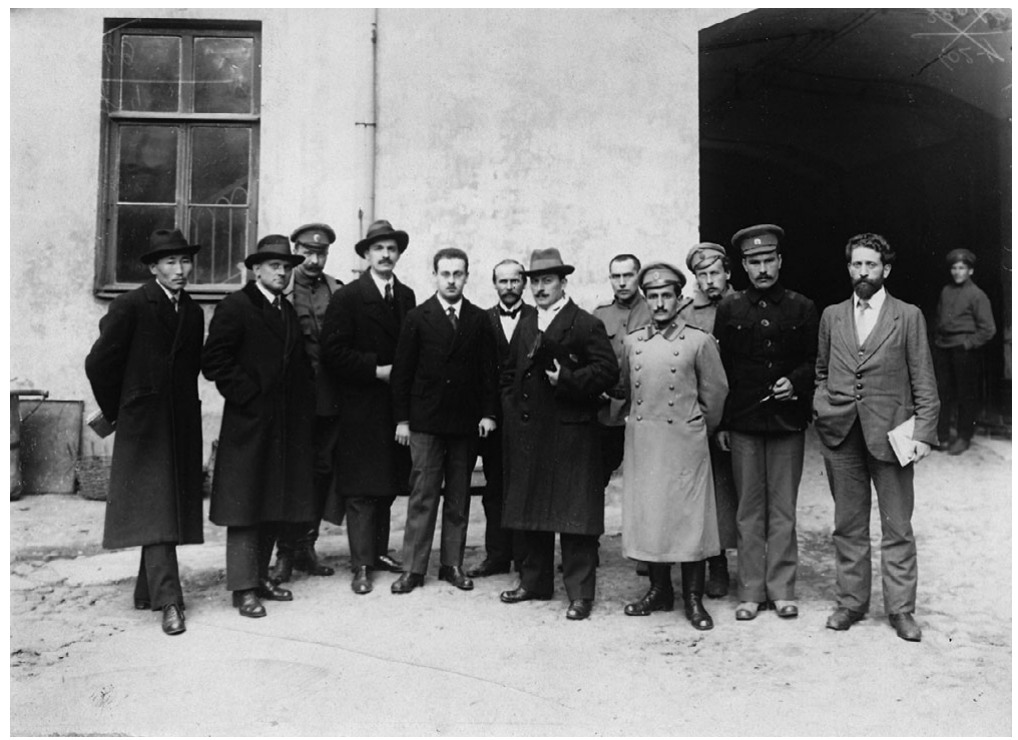

Figure 6. Representatives of the Committee of National Socialist Factions at the All-Russian Democratic Conference, Petrograd, September 1917. TsGAKFFD SPb, D 19727. Left to right: D. S. Sampilon (first), I. I. Shimanovich (second), F. Kemp (third), I. I. Voronko (fourth), N. I. Baru (fifth), A. Piip (eighth); in no particular order: V. I. Nutsubidze, S. G. Bagir'ian, M. L. Gutman.

promised. The Congress also supported the convocation of national constituent assemblies irrespective of the All-Russian one for deciding on the relations with the central federal bodies and on internal organization of nationalities. Finally, it created a standing Council of Peoples and sent a delegation to the Democratic Conference (Dimanshtein, Levin, and Drabkina 1930, 443-49).

The discussion of the nationality question at the Democratic Conference left a poor impression on the non-Russian delegates. Many delegates had left before the discussion and the Chairman attempted to limit the time for speeches and even to close the meeting. Noi Isaakovich Baru of the Marxist-Zionist Poale Zion denounced such a lack of attention to the nationality question and acknowledged that there was a gap between the Russian "revolutionary democracy" and the "democracies" of individual peoples. The Georgian Varlam Isakovich Nutsubidze, who spoke on behalf of the Council of National Socialist Parties of Russia (figure 6), which united Belarusian, Lithuanian, Jewish, Estonian, Polish, Ossetian, Buryat, Georgian, Ukrainian, and other organizations, denounced the shouts and ironic exclamations from the audience during the speeches of the non-Russian representatives. Iosif Iakovlevich Voronko of the Belarusian Central Rada reminded the Conference that the non-Russian nationalities were a majority in Russia's population. ${ }^{38}$

The representatives of non-Russian organizations reaffirmed most of the decisions of the Kyiv Congress, including the immediate introduction of federative principles with territorial and nonterritorial autonomy, the equality of languages, the formation of the Council of Nationalities, and the right to convene national constituent assemblies. Understanding Russia as a "conglomerate of peoples," Aleksandr Ivanovich Sobolevskii of the Belarusian military organization called for the liberation of Russia's nationalities without any concealed thoughts of Russian supremacy. The Council of National Socialist Parties demanded "immediate proclamation of the Russian federative republic" with the right of national minorities to personal autonomy. Voronko also suggested introducing a position of the Minister of National Affairs to be selected from the Council of Nationalities. Whereas the federative approach predominated, some speakers also left the issue of secession open. The Lithuanian Nikolai Osipovich Ianushkevich (Ianushevich) urged the Provisional Government to formally recognize the right of the Lithuanian people to self-determination through the Lithuanian Constituent Assembly. Porsh of the Ukrainian Central Rada (figure 7) 


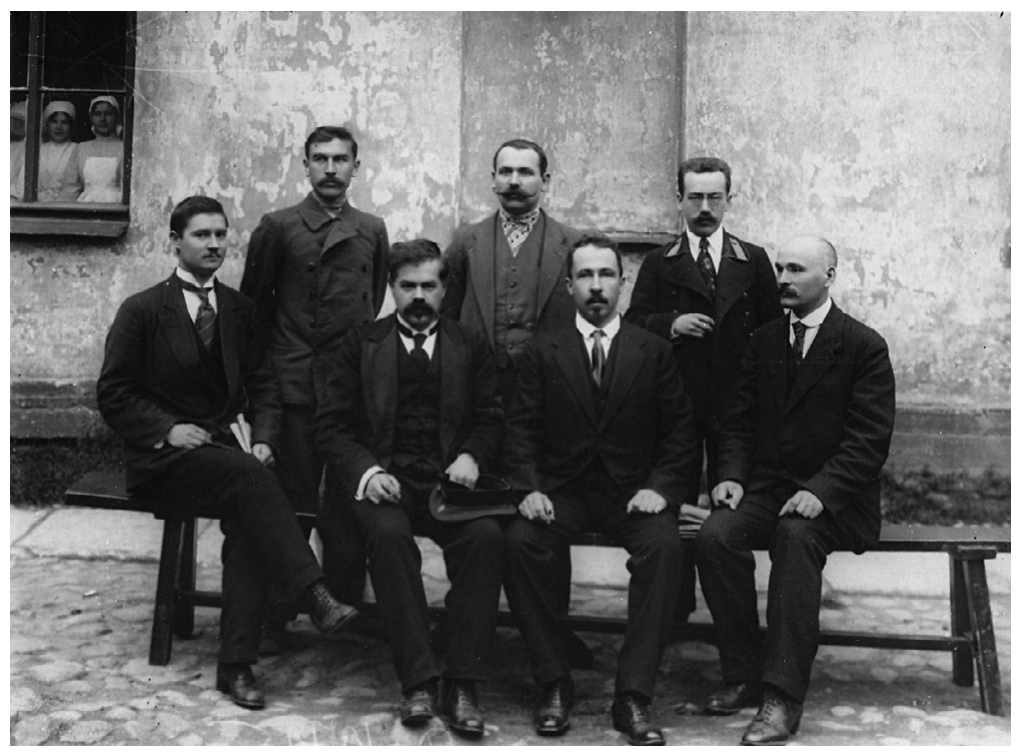

Figure 7. Representatives of the Ukrainian Central Rada at the All-Russian Democratic Conference, Petrograd, September 1917. TsGAKFFD SPb, D 19725. Seating, left to right: P. A. Khristiuk, N. E. Shapoval, N. V. Porsh, M. S. Tkachenko; standing, left to right: I. G. Dovgii, B. B. Babich, S. P. Vikul.

openly supported the Finnish independence movement (there were no Finnish representatives at the Conference), which was denounced in liberal press. ${ }^{39}$

Some speakers focused on the problems of individual groups. The declaration of the Ukrainian Central Rada pointed to the errors of the "revolutionary democracy" in the nationality question in Russia in general and in Ukraine in particular, since it understood the organization of the masses under the banner of "national territorial autonomy of Ukraine," the banner of "federalism and the equality of all peoples of Russia," as separatism. It then called for trust to non-Russian nationalities, for proper recognition of the Ukrainian authorities, and for the inclusion of additional territories into self-governing Ukraine. The reading of the declaration was interrupted by the audience. Voronko demanded immediate autonomy for Belarus in view of the German advances, so that such a decision would not be seen as one forced by occupation, like it had been in the case of Poland. ${ }^{40}$

Akhmed (Akhmet) Tembulatovich Tsalikov of the All-Russian Muslim Council maintained that the Russian Muslims grew dissatisfied with the revolutionary regime due to the inadequate religious policies of the Provisional Government, with some of the Tsarist officials still in place. He also denounced the plans for expropriating indigenous lands by Chernov's Ministry of Agriculture and the violence of settlers, soldiers, and deserters against the indigenous population of Khiva. Tsalikov condemned the continued treatment of the peoples of the East as a "lower race" and criticized the dismissal of the Muslims' proposals for the elections to the Constituent Assembly, such as the introduction of mobile ballot boxes for the nomadic herders and a separate day for the Muslim women's vote. He proposed forming the Secretariat on Muslim Affairs under the Provisional Government. Tsalikov suggested that the continued colonial practices should push the Muslims to the far left and make them supporters of soviet rule, since only the working class was their ally, but advocated a broader coalition. According to Tsalikov, the lack of workers and soldiers among the Muslims left them with no constituent elements for a soviet government. He also mentioned several cases of violence perpetuated by the "masses" which followed soviets. ${ }^{41}$

Similar to the Kyiv Congress, multiple speakers called for the reorganization of the Army on the principle of nationality. Osman (Usman) Gidaiatullovich Tokumbetov of the Muslim military organization viewed it as a means of reinstating trust between soldiers and officers. Speaking of the Muslim detachments, he stressed that the shared faith would be a major factor facilitating trust and 
discipline. Elizar Il'ich Machabeli of the Georgian military organization specified that operations had to be localized, as it was "too cold in the North" for the Georgians and they were better suited for defending the Caucasus. Some called for separate national armies. ${ }^{42}$

Despite the evident negligence of non-Russian interests by the proponents of class rhetoric at the Democratic Conference, the speakers for the non-Russian groups predominately opposed a broader coalition, combining socialist and nationalist approaches. The delegate of the Kyiv Congress spoke for a coalition but without the KDs who rejected federation. Baru specified that a coalition with the "propertied elements" was not possible since they opposed self-organization of the masses in general and federalism in particular. The delegation of the Ukrainian Central Rada called the KD opposition to the Ukrainian authorities "a crime against the country" and branded those implicated in the Kornilov Affair as traitors who betrayed the Motherland for the "interests of international capital." Nutsubidze stressed that the "peoples of Russia" suffered in a double manner, "being deprived of citizen rights and being deprived of national rights" and argued that the struggle for social and national ideals was indivisible. The Buryat Dashi Sampilovich Sampilon also spoke of double oppression but in fact added a third level when speaking of the "oppressed race and people." 43

Some speakers stressed the global anti-colonial implications of the Russian Revolution. Tsalikov claimed that the sleeping peoples were awakening ${ }^{44}$ and moving towards the "beacon of freedom," which had been lit in Russia. He argued, however, that the Russian "revolutionary democracy" did not complete its tasks in the Russian East and made mistakes. According to Tsalikov, the peoples of the East did not know if the right to self-determination was also applied to them when the Russian "democracy" spoke to "Western Europe." Nutsubidze argued that "the Russian democracy has to be the first to set an example" for the world by "liberating the peoples in their own country." Sampilon maintained that the freedom of Russia's "hundred plus nationalities" had the historical importance as the beginning of the revolutionary liberation movement of the "democracy" of all peoples of the world. At the same time, he stressed that this freedom had its own value irrespective of the rest of the world. ${ }^{45}$

Regionalist ideas were also articulated in the debates revolving around the issue of minorities. Porsh described Ukraine as a region, which had its own revolutionary nation of multiple nationalities (Ukrainian, Russian, Jewish, and others), as represented by the Central Rada. He also specified that each national region had the right to convene its own constituent assembly. Sobolevskii spoke of "peoples-regions." Abramovich stressed the importance of minority rights in the new units, so that the state nation would not give way to multiple oppressing nationalities. The issue of minorities was also raised in the declaration of the Moldavian Committee of the Romanian Front, which protested the alleged desires of the Ukrainian Central Rada to annex Bessarabia. ${ }^{46}$

There were also appeals to nationality in the Pre-Parliament, where non-Russian groups formed a bloc. The Pre-Parliament created a commission on national affairs under the Lithuanian SR Andrei Andreevich Bulat (Andrius Bulota) but it also suffered from the lack of quorum. The socialist and non-socialist Jewish members of the Council, which disagreed on many issues, acted jointly on the matters related to the Jews and inquired the Provisional Government about measures against anti-Jewish pogroms. The speakers of the Council of National Socialist Parties reaffirmed its demand to reorganize the Army on the nationality principle. Tsalikov and other non-Russian politicians prepared the question to the Provisional Government on the progress in the establishment of the Council of National Affairs, which was supposed to be discussed on October $25 .{ }^{47}$

The presence of non-socialist groups, however, made the nationality question even more contested than at the Democratic Conference. After the SR War Minister Verkhovskii supported the formation of national detachments and the switch to a territorial system, claiming that there already were de facto "Ukrainian, Estonian, Georgian, Tatar" detachments, the KD Adzhemov accused him of mixing up territorial and national principles, implying that only the former was permissible. The non-socialist Minister of Foreign Affairs Tereshchenko argued that Germany 
planned to separate Russia from the West and that this separation was to be carried out by "peaceful secession of certain buffer units," which would ensure takeover of Russia through goods and labor. Tereshchenko opposed the point on full self-determination of "Lithuania and Latvia" in the instructions to the Menshevik Matvei Ivanovich Skobelev, who was supposed to represent the "democracy" at the anticipated Allied conference. The KD Pavel Nikolaevich Miliukov also denounced the instructions and rebuked the decision in favor of independence, made by the Lithuanian Sejm in Vilnius in September 1917. He then lambasted the idea of the Ukrainian Constituent Assembly, claiming that the plan for its independence was sponsored by Germany. He concluded that self-determination with the right to secession helped the German plans of creating buffer states. Milukov's speech was interrupted by shouts from the left. ${ }^{48}$

Moderate socialists, however, also attempted to downplay the self-determination slogans. Dan argued that self-determination did not mean independence and that "the connection to the Great Russian Revolution" was beneficial for "for the success of class struggle of all toilers." He also dismissed the decision of the Lithuanian Sejm, since it was not led by the toiling classes. ${ }^{49}$

The Lithuanian Ianushkevich accused the Provisional Government of obstructing the strive of peoples to self-determination and defended the instructions to Skobelev. At the same time, he agreed that the Sejm in Vilnius did not represent the true will of the Lithuanian people, concluding that the "Lithuanian democracy" connected "its destiny to the Revolution in Russia," but nevrtheless argued that Russia had to be a union of equals. Aleksei Karpovich Dzhivelegov of the Armenian Revolutionary Federation (Dashnaktsutiun) argued that it was the duty of the Russian people to help Armenia gain independence, since it would consolidate the "brotherly ties between the great Russian people and its younger brother, the Armenian people." 50

Non-Russian press was critical of the two assemblies. Vil'na Ukraina was disappointed with the results of the Democratic Conference, since the "democracy" refused to take power, while the Provisional Government continued its previous policies, postponing the resolution of the national question. Commenting on the debates in the Pre-Parliament and Russian politics in general, the Belarusian philologist and politician Jazep Losik criticized the "Russian (Muscovite) democracy" for its dismissal of national demands and concluded that there was no hope for the Russian Constituent Assembly and instead called for the Belarusian Constituent Assembly. ${ }^{51}$

\section{Russian Postimperial Community}

While some political groups advocated exclusionary community-building based on class or nationality, many speakers at the Democratic Conference and in the Pre-Parliament continued to articulate their visions of an inclusionary Russian political community. Representatives of most political forces, including the Bolsheviks, cited the interests of the Russian nation or people. Yet, no coherent project of such a heterogeneous community prevailed. Furthermore, the slogans of inclusiveness often did not translate into viable policy proposals, while the Russian nationalist slogans often called for postponing or abandoning the satisfaction of particularistic interests.

The invitations to the Democratic Conference, signed by Chkheidze and Avksent'ev, formulated its main goals in national defencist terms. They cited the "difficult days" of the "Motherland," when "treason and betrayal" threatened "it with a military defeat and internal turmoil." The invitations prompted to "gather all the forces of the country in order to organize its defense," facilitate "its internal order," and decide on a "strong revolutionary authority, capable of uniting whole revolutionary Russia" for "repelling external enemies and suppressing any encroachments on the freedom it has won." 52 When Tsereteli proposed the formation of a coalitional Provisional Government ahead of the Conference, he cited the need to unite "all living forces of the country," an idea which predominated at the State Conference in Moscow. The VTsIK and the SR Central Committee supported the idea of coalition but excluded the KDs from it. ${ }^{53}$

The Menshevik-Defencist Chkheidze reaffirmed the nationalist framing of the Conference on its first day, claiming that Russia was in danger due to the legacies of Tsarism and especially the war. 


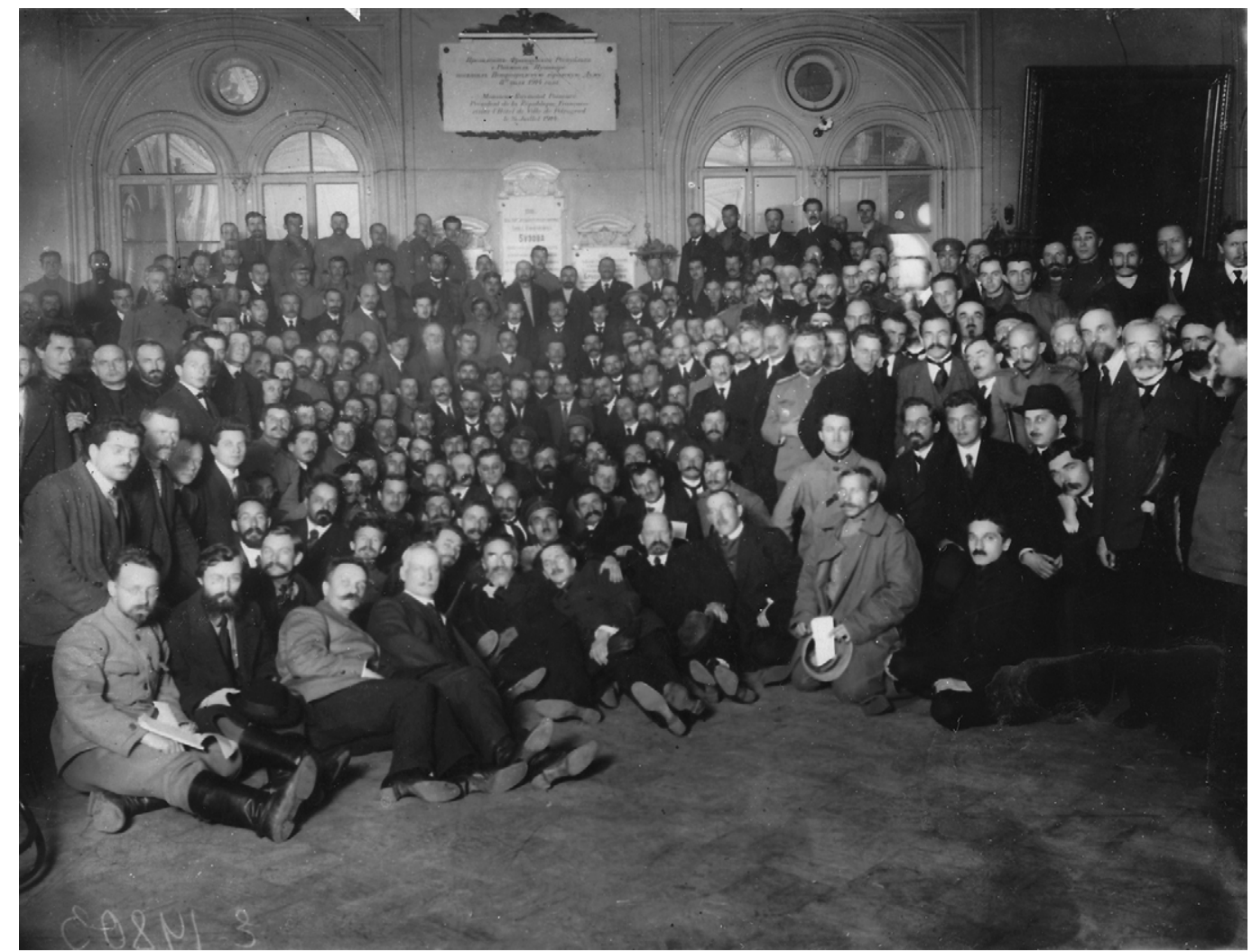

Figure 8. The proponents of coalition at the All-Russian Democratic Conference, Petrograd, September 1917. TsGAKFFD SPb, E 14803. N. D. Avksent'ev, M. I. Skobelev, and I. G. Tsereteli are in the center of the group.

He claimed that the Revolution was supposed to discover "all creative forces of the nation" for defending the country and achieving a peace, but instead both the "imperialist circles" and the proponents of the immediate world social revolution undermined the war effort, provoked anarchy, and made the German danger to Petrograd possible. According to Chkheidze, the Conference needed to mobilize those forces which would support a moderate socialist program. The SR Avksent'ev added that ensuring the independence of the Motherland and creating "statehood and solid state authority" were the main tasks of the "democracy." ${ }^{4}$

Many delegates articulated or implied nationalism and etatism inclusive of class when advocating a coalition (figure 8). Aleksei Vasil'evich Peshekhonov of the Toiling People's Socialist Party reiterated the non-socialist slogans of the State Conference, deeming the program of "group" (class and nationality) claims dangerous for the state. He argued that the unified state had to be defended through self-limitation by all groups, especially the toiling classes, and through a coalition on the basis of submitting class interests to state interests. Avksent'ev and Dan called for a coalition with the "propertied elements" on the basis of the August 14 platform, while Berkengeim called for a coalition of "all living forces" and for the all-national self-sacrifice of all classes. ${ }^{55}$

Some non-Russian speakers advocated a coalition as inclusive of nationalities. Tokumbetov spoke of the "Russian [rossiiskie] citizens," argued that only the unity "of all living forces of the country" could save the Motherland and the Revolution, and reaffirmed the Muslims' loyalty to Russia. Israel' Rafailovich Efroikin of the Jewish national group, Liparid Iosifovich Nazariants of the Armenian Revolutionary Federation, Aitech Alievich Namitokov of the Mountaineers of the North Caucasus and Dagestan, and several others urged to postpone the final resolution of the nationality question until the Constituent Assembly. Akakii Ivanovich Chkhenkeli, who spoke on behalf of the 
Georgian nation, called Russia an internationalist state but claimed that the Georgian "national feeling" was hard to distinguish from the "all-state Russian [rossiiskii] feeling." He also argued that nobody spoke of the interests of the Russian [russkii] nation (in the ethnic sense). It is important to note that the Georgian Mensheviks-Defencists, Chkheidze and Tsereteli in the first place, were among the most prominent all-Russian politicians of the Revolution's first months. ${ }^{56}$

The bottom-up approach to Russia's self-organization predominated at the Democratic Conference, but there was no agreement on its form. The joint declaration of workers' and soldiers' soviets argued that the soviets were the bearers of the idea of democracy (narodovlastie) but acknowledged the need to work in contact with all other organizations-self-government bodies; military organizations; land, factory, and provisions committees; cooperatives; and trade unions. According to the declaration, this network of democratic organizations ensured Russia's integrity. Most of the zemstvo delegates argued, however, that the universally elected zemstvo was the foundation on which Russian state-building had to continue. ${ }^{57}$

The Russian community was often cited in the Pre-Parliament, especially in the context of the war. Breshkovskaia urged the "Russian citizens" to observe the needs of the country. Avksent'ev argued that the "great enthusiasm of the people" could save the Motherland in the war. Comparing Russia to the French Republic in the late eighteenth century, he again urged "all living forces of the country," the people of "different classes, different parties," to unite for defense. ${ }^{58}$

The Russian Army was hardly a fighting force in the fall of 1917, but non-socialists and some socialists advocated Russia's continued participation in the First World War. General Mikhail Vasil'evich Alekseev, who spoke on behalf of the Moscow Council of the Conference of Public Figures, opposed the popular slogan of immediate peace, since such peace would lead to the demise of Russia as a state and to the "division of its possessions," reaffirmed the need to reinstate discipline in the Army, and urged the Pre-Parliament to make the fight until victory its main task. Miliukov went as far as reaffirming the need to take over the Dardanelles and the Bosporus, the point which led to his resignation as Minister of Foreign Affairs in May. Some non-socialists, however, specified that since large parts of Russia were occupied, the goal of the war was to defend the integrity of its territory. ${ }^{59}$

The defencist slogans predominated. War Minister Verkhovskii argued that Germany tried to force a shameful peace on Russia and that the Provisional Government and that the Pre-Parliament had to explain to the fighters that the war was waged only for saving the Motherland. How the Army and the country were to be organized for defense remained disputed. Some were for a top-down approach. Ekaterina Dmitrievna Kuskova, who represented cooperatives and was soon expelled from the Menshevik Party for her views, Liubov' Isaakovna Aksel'rod (Ortodoks) of the Unity Group, Nikolai Vasil'evich Chaikovskii of the Toiling People's Socialist Party, and others admitted that coercion was needed and called for postponing reforms. The draft resolution on defense, proposed by Chaikovskii and supported by the representatives of cooperatives, right socialists, and most non-socialists, argued that the main task of the Pre-Parliament was to strain the moral and material forces of all Russia's "groups, classes, and nationalities" for repelling the enemy and for defending the integrity and independence of the Motherland. It also called for harsh measures against anarchy and for postponing reforms. ${ }^{60}$

Others continued to speak of bottom-up self-organization. The SRs and Mensheviks-Internationalists advocated further democratization of the Army, including the strengthening of military organizations and the abolition of the death penalty. The non-partisan Navy Minister Dmitrii Nikolaevich Verderevskii argued that discipline could not be reinstated with violence and supported further cooperation with the sailors' organizations. The SR draft resolution on defense reaffirmed the defensive objectives of the war, called for a foreign policy promoting universal peace without annexations and contributions on the basis of national self-determination, and reiterated the party's democratization proposals. The last socialist resolution of the Pre-Parliament urged the government to propose to the Allies that peace talks should begin. The Allies, however, remained unreceptive to the proposals of peace, especially after the USA entered the war. ${ }^{61}$ 
The Bolsheviks, the most vocal proponents of an immediate peace, were often labelled as traitors and enemies of Russia. Most of the Cossack faction agreed that they hampered the unification of "all living forces." Alekseev implied that all those who called for an immediate peace were traitors, while Miliukov viewed the peace initiatives of the left in the instructions to Skobelev as facilitating German interests. On October 24, Kerenskii accused the Bolsheviks of treason and claimed that those groups and parties which threatened the free will of the Russian people and could open the front to Germany needed to be eliminated. At the same time, the Bolsheviks themselves made use of patriotic slogans in view of the ostensible danger to Petrograd. The Bolshevik declaration, delivered by Trotskii, argued that the salvation of the country was in the peace agreement and accused the Provisional Government of "treason" against the people in view of the allegedly coming surrender of Petrograd to the Germans. The danger to Petrograd and the need to mobilize the Petrograd garrison for saving the city were mentioned in the resolution of the Petrograd Soviet, adopted in response to the Bolshevik declaration in the PreParliament. ${ }^{62}$

After the Bolshevik walkout, some of the remaining delegates continued to stress that ending the war as soon as possible was beneficial to the nation. Abramovich argued that the desire for an immediate end to the war was "healthy national egoism," and that the Allies needed to be informed that Russia did "not want to fight anymore." Although he still voiced the slogan of "peace without annexations and contributions," he admitted that a separate peace agreement between Russia and the Central Powers seemed the only way out. Baru argued that internationalism was not a rejection of the Motherland but an affirmation of a democratic Motherland. The Menshevik-Internationalist resolution on defense called for an immediate truce. The left SRs also called for an immediate end to the war. ${ }^{63}$

\section{Conclusion}

The plans to create a provisional parliament, to which the Provisional Government would be accountable, failed. A unified socialist government had also not been created. This left the government lacking legitimacy and vulnerable to Bolshevik attacks. The Democratic Conference and the Pre-Parliament amplified the notions of class and nationality difference and reaffirmed the slogans of immediate social reforms and the proclamation of a federative republic. The proponents of particularistic group interests opposed a coalitional government, since non-socialists were seen as a threat to both the toiling classes and the non-Russian nationalities. Even though many still spoke of Russian national interests and called for unity, the debates in the Pre-Parliament demonstrated that the top-down and bottom-up approaches to the building of a postimperial political community could hardly be reconciled. These splits largely informed the multilayered postimperial Civil War (Smele 2015). No coherent program of inclusionary community-building came out of the two assemblies.

Advocating class and nationality interests did not necessarily mean joining or supporting the Bolsheviks. The Bolsheviks, however, made significant adjustments to their initial program. They retained the discourse of class-based community but also made the nationality issue prominent. Their political project acquired an explicitly dual, class and nationality, character when Soviet Russia was proclaimed both as a polity of soviets and as a federative republic of nationalities in January 1918 (Sablin and Semyonov 2020; Suny 1993).

Disclosures. None.

Financial Support. The research for this article was done as part of the project "ENTPAR: Entangled Parliamentarisms: Constitutional Practices in Russia, Ukraine, China and Mongolia, 1905-2005," which received funding from the European Research Council (ERC) under the European Union's Horizon 2020 research and innovation program (grant agreement No 755504). 


\section{Notes}

1 The article used "democracy" in quotation marks when this meaning was being implied.

2 Gosudarstvennyi arkhiv Rossiiskoi Federatsii (GARF), f. 1798, op. 1, d. 7, 8 (Report on the Fourth Day of the All-Russian Democratic Conference, September 18, 1917).

3 The consolidation of "non-socialist" forces as a distinct political grouping of liberals, business elites, and segments of the right took an institutional shape at the Moscow Conference of Public Figures in August 1917 and was fostered by the cooperation between the groups represented there and the KD Party (Seleznev 2007).

4 Vol'naia Belarus', October 26, 1917, 1.

5 There was no strict differentiation between the adjectives russkii and rossiiskii (both meaning "Russian") at the time, although the proponents of the composite approach tended to use the latter.

6 The Mensheviks and the SRs had multiple factions at the time. In the former case, the Mensheviks-Internationalists and the Mensheviks-Defencists were discussed separately when a distinction was important in the context of the debates. In the latter, the left SRs, which were formally not a separate party until November 1917, were the most significant faction.

7 Despite the presence of the "All-Russian Soviet" in its name, it was a standing body, which was formed at the First All-Russian Congress Peasants Deputies and hence represented multiple organizations of peasants and soldiers, many of which eventually took the form of soviets, rather than a singular central soviet.

8 Delo naroda, September 13, 1917, 3.

9 The term described cooperative, predominately consumer, societies which included representatives of all imperial social estates.

10 At the time, the category of "Muslim" was often used to collectively describe several national, predominantly Turkic, groups.

11 GARF, f. 1798, op. 1, d. 8, 2, 8 (Report on the Fifth Day of the All-Russian Democratic Conference, September 19, 1917); Delo naroda, September 14, 1917, 1; September 16, 1917, 3; Narodnoe slovo, September 19, 1917, 1; Rech', September 15, 1917, 3; Sotsial-Demokrat, September 13, 1917, 1; Vechernee vremia, Setember 15, 1917, 2; Vol'nyi golos Severa, September 7, 1917, 1; Vpered!, September 17, 1917, 1.

12 GARF, f. 1798, op. 1, d. 8, 1, 3-4, 6-7, 10-12.

13 GARF, f. 1798, op. 1, d. 9, 1-2, 4-7 (Report on the Meeting of the Representatives of Factions with the Presidium of the All-Russian Democratic Conference, 20 September 1917); GARF, f. 1798, op. 1, d. 10, 1-15 (Report on the Sixth Day of the All-Russian Democratic Conference, 20 September 1917); GARF, f. 1798, op. 1, d. 12, 12 (Report on the Eight Day of the All-Russian Democratic Conference, 22 September 1917); Savel'ev and Rakhmetov 1929, 70.

14 Russkie vedomosti, September 22, 1917, 3.

15 Edinstvo, September 17, 1917, 1.

16 Anarkhiia, September 18, 1917, 1; September 15, 1917, 1.

17 Delo naroda, September 23, 1917, 3-4; September 25, 1917, 2; September 26, 1917, 2; Rech', September 23, 1917, 3-4; September 26, 1917, 4; Vpered!, September 26, 1917, 2; for an incomplete list of members of the Pre-Parliament, see Raikhtsaum 1993b.

18 Delo naroda, September 26, 1917, 2.

19 Rech', October 3, 1917, 1.

20 Anarkhiia, October 2, 1917, 1.

21 The five-year term of the Fourth Duma was ending in October 1917 anyway.

22 Rech', October 1, 1917, 1; Vestnik Vremennogo pravitel'stva, October 3, 1917, 1.

23 Rech', October 7, 1917, 4; October 10, 1917, 4; October 18, 1917, 4; Vestnik Vremennogo pravitel'stva, October 15, 1917, 4; Rudneva 2006, 69-70, 72, 89, 103.

24 Rech', October 8, 1917, 2; Vestnik Vremennogo pravitel'stva, October 8, 1917, 3; Vpered!, October 8, 1917, 1. 
25 Rech', October 8, 1917, 3; October 18, 1917, 4.

26 GARF, f. 1799, op. 1, d. 6, 15 (Report on the Meeting of the Provisional Council of the Russian Republic, October 23, 1917); Rech', October 14, 1917, 3; October 17, 1917, 3; October 19, 1917, 2-3; Vestnik Vremennogo pravitel'stva, October 11, 1917, 2; October 14, 1917, 2; October $15,1917,4$.

27 Rech', October 25, 1917, 2; October 26, 1917, 2; Sovremennoe slovo, October 25, 1917, 2.

28 Delo naroda, September 13, 1917, 3.

29 GARF, f. 1798, op. 1, d. 3, 20-22, 25-27 (Report on the First Day of the All-Russian Democratic Conference, September 14, 1917); GARF, f. 1798, op. 1, d. 5, 6-7, 12, 14 (Report on the Third Day of the All-Russian Democratic Conference, September 16, 1917); GARF, f. 1798, op. 1, d. 7, 30, 32; GARF, f. 1798, op. 1, d. 8, 2.

30 Delo naroda, September 20, 1917, 1.

31 GARF, f. 1798, op. 1, d. 5, 15; GARF, f. 1798, op. 1, d. 17, 37-38 (Verbatim Report of the Third Day of the All-Russian Democratic Conference, September 16, 1917); Edinstvo, September 19, 1917, 1; Rech', September 15, 1917, 2.

32 GARF, f. 1798, op. 1, d. 5, 21; GARF, f. 1798, op. 1, d. 7, 17, 32; GARF, f. 1798, op. 1, d. 17, 43-45.

33 GARF, f. 1798, op. 1, d. 5, 7-8; Izvestiia Soveta rabochikh i soldatskikh deputatov gor. Tiflisa, October 7, 1917, 3.

34 GARF, f. 1799, op. 1, d. 13, 2 (Application No. 8 on the Appeal to the Minister-President and the Minister of Internal Affairs with the Question on the Violent Actions of Cossack Detachments in Kaluga towards the Soviet of Workers' and Soldiers' Deputies, submitted on October 23, 1917); Rech', October 8, 1917, 3; October 11, 1917, 4; October 13, 1917, 3; October 14, 1917, 3; October 19, 1917, 2; October 25, 1917, 2; Vestnik Vremennogo pravitel'stva, October 14, 1917, 3.

35 GARF, f. 1799, op. 1, d. 5, 1, 19 (Report on the Meeting of the Provisional Council of the Russian Republic, October 20, 1917); Rech', October 8, 1917, 3; October 11, 1917, 4; October 13, 1917, 2.

36 Rech', October 25, 1917, 2.

37 GARF, f. 1799, op. 1, d. 14, 2, 4 rev. (Application No. 9 on the Appeal to the Ministers of Trade and Industry, Internal Affairs, Justice, and Labor with the Question on the Possible Strike at the Textile Enterprises of the Central Industrial District and the Takeover Thereby of Factories by the Strike Committee, submitted on October 23, 1917); Rech', October 13, 1917, 2; October $25,1917,2$.

38 GARF, f. 1798, op. 1, d. 17, 20, 33, 45, 48, 50, 68-69.

39 GARF, f. 1798, op. 1, d. 5, 20; GARF, f. 1798, op. 1, d. 17, 12-15, 35-37, 66, 70; Sovremennoe slovo, September 19, 1917, 1.

40 GARF, f. 1798, op. 1, d. 17, 8-11, 71, 77.

41 GARF, f. 1798, op. 1, d. 5, 23-29.

42 GARF, f. 1798, op. 1, d. 17, 1-4, 11-12, 15-17, 29, 37.

43 GARF, f. 1798, op. 1, d. 5, 5-7; GARF, f. 1798, op. 1, d. 8, 1; GARF, f. 1798, op. 1, d. 17, 34, 36, 49-50, 75.

44 The metaphor of the awakening of Asian countries and peoples was commonly used at the time (Wagner 2011).

45 GARF, f. 1798, op. 1, d. 17, 20-22, 36, 75-76.

46 GARF, f. 1798, op. 1, d. 17, 14, 20, 39, 77.

47 GARF, f. 1799, op. 1, d. 12, 2, 8 (Application No. 7 on the Appeal to the Provisional Government with the Question on the Development and Submission to the Provisional Council of the Draft Resolution on the Establishment of the Council of National Affairs, submitted on October 23, 1917); GARF, f. 1799, op. 1, d. 29, 10 (Agenda of the Tenth Meeting of the Provisional Council of the Russian Republic, October 25, 1917); Rech', October 11, 1917, 4; October 13, 1917, 3; October 14, 1917, 3; October 22, 1917, 3; Vestnik Vremennogo pravitel'stva, October 15, 1917, 4.

48 Rech', October 13, 1917, 2; October 19, 1917, 3; Vestnik Vremennogo pravitel'stva, October 11, 1917, 2; October 17, 1917, 3-4. 
49 GARF, f. 1799, op. 1, d. 5, 7.

50 GARF, f. 1799, op. 1, d. 5, 14; GARF, f. 1799, op. 1, d. 6, 2.

51 Vil'na Ukraina, October 1, 1917, 1; Vol'naia Belarus': October 26, 1917, 1.

52 GARF, f. 1798, op. 1, d. 1, 42 (To the Union of Women's Democratic Organizations from Chkheidze and Avksent'ev, 1917).

53 Delo naroda, September 13, 1917, 3; September 14, 1917, 1.

54 GARF, f. 1798, op. 1, d. 3, 2-4.

55 GARF, f. 1798, op. 1, d. 4, 14-16 (Report on the Second Day of the All-Russian Democratic Conference, September 15, 1917); GARF, f. 1798, op. 1, d. 5, 15-16; GARF, f. 1798, op. 1, d. 7, 23-24. Some opponents of coalition also appealed to unity. Priest Aleksandr Ivanovich Vvedenskii, who represented the All-Russian Union of Democratic Orthodox Clergy and Laity and was the only religious figure at the Conference, spoke of class selfishness as the reason for the lack of unity for saving the Motherland but opposed coalition. GARF, f. 1798, op. 1, d. 7, 7.

56 GARF, f. 1798, op. 1, d. 17, 1-4, 15-17, 29-31, 61, 63, 83-84; Rech', September 20, 1917, 2.

57 GARF, f. 1798, op. 1, d. 5, 9; GARF, f. 1798, op. 1, d. 7, 19-20.

58 Rech', October 8, 1917, 3; Vestnik Vremennogo pravitel'stva, October 8, 1917, 3.

59 GARF, f. 1799, op. 1, d. 5, 14-15; Rech', October 11, 1917, 4; October 13, 1917, 2; October 19, 1917, 3-4; Smith 2017, 147.

60 Rech', October 13, 1917, 2-3; October 19, 1917, 2; Vestnik Vremennogo pravitel'stva, October 11, 1917, 2.

61 Rech', October 11, 1917, 4; October 13, 1917, 3; October 17, 1917, 2; October 19, 1917, 3; October 25, 1917, 2; Vestnik Vremennogo pravitel'stva, October 17, 1917, 1-2; Engelstein 2018, 174.

62 Rech', October 8, 1917, 3; October 10, 1917, 4; October 11, 1917, 4; October 13, 1917, 3; October 19, 1917, 3-4; October 25, 1917, 2.

63 GARF, f. 1799, op. 1, d. 6, 1, 10-11; Rech', October 17, 1917, 2; October 19, 1917, 3.

\section{References}

Berger, Stefan, and Alexei Miller. 2015. "Introduction: Building Nations in and with Empires-A Reassessment”. In Nationalizing Empires, edited by Stefan Berger and Alexei Miller, 1-30. Budapest: Central European University Press.

Brubaker, Rogers. 1998. "Myths and Misconceptions in the Study of Nationalism." In The State of the Nation: Ernest Gellner and the Theory of Nationalism, edited by John A. Hall, 272-306. Cambridge: Cambridge University Press.

Burbank, Jane. 2006. “An Imperial Rights Regime: Law and Citizenship in the Russian Empire.” Kritika: Explorations in Russian and Eurasian History 7 (3): 397-431.

Demin, V. A. 1996. Gosudarstvennaia duma Rossii: Mekhanizm funktsionirovaniia. Moscow: ROSSPEN.

Dimanshtein, Semen Markovich, I. Levin, and E. Drabkina, eds. 1930. Revoliutsiia i natsional'nyi vopros: Dokumenty i materialy po istorii natsional'nogo voprosa v Rossii i SSSR v XX veke. Vol. 3: 1917, fevral'-oktiabr'. Moscow: Izdatel'stvo Kommunisticheskoi akademii.

Engelstein, Laura. 2018. Russia in Flames: War, Revolution, Civil War, 1914-1921. New York: Oxford University Press.

Gerasimov, Ilya. 2017. “The Great Imperial Revolution.” Ab Imperio 2: 21-44.

Ihalainen, Pasi, Cornelia Ilie, and Kari Palonen. 2016. "Parliament as a Conceptual Nexus." In Parliaments and Parliamentarism: A Comparative History of a European Concept, edited by Pasi Ihalainen, Cornelia Ilie, and Kari Palonen, 1-16. New York: Berghahn Books.

Kolonitskii, Boris Ivanovich. 1998. "Democracy' in the Political Consciousness of the February Revolution." Slavic Review 57 (1): 95-106.

Kolonitskii, Boris Ivanovich. 2012. Simvoly vlasti i bor'ba za vlast': K izucheniiu politicheskoi kul'tury revoliutsii 1917 goda. 2nd ed. Saint Petersburg: Liki Rossii.

Orlovsky, Daniel. 1997. “Corporatism or Democracy: The Russian Provisional Government of 1917.” The Soviet and Post-Soviet Review 24 (1): 15-25.

Raikhtsaum, A. L. 1993a. "14-22 sentiabria: Vserossiiskoe Demokraticheskoe soveshchanie.” In Politicheskie deiateli Rossii 1917: Biograficheskii slovar’, edited by P. V. Volobuev, 383-84. Moscow: Bolshaia Rossiiskaia entsiklopediia.

Raikhtsaum, A. L.. 1993b. "Spisok chlenov i kandidatov v chleny Vremennogo Soveta Rossiiskoi Respubliki (Predparlamenta).” In Politicheskie deiateli Rossii 1917: Biograficheskii slovar', edited by P. V. Volobuev, 386-90. Moscow: Bolshaia Rossiiskaia entsiklopediia.

Rudneva, Svetlana Evgen'evna 2000. Demokraticheskoe soveshchanie, sentiabr' 1917 g.: Istoriia foruma. Moscow: Nauka. 
Rudneva, Svetlana Evgen'evna. 2006. Predparlament, oktiabr' 1917 g.: Opyt istoricheskoi rekonstruktsii. Moscow: Nauka.

Sablin, Ivan, and Alexander Semyonov. 2020. "Autonomy and Decentralization in the Global Imperial Crisis: The Russian Empire and the Soviet Union in 1905-1924.” Modern Intellectual History 17 (2): 543-60.

Savel'ev, Maksimilian Aleksandrovich, and V. N. Rakhmetov, eds. 1929. Protokoly Tsentral'nogo komiteta RSDRP, avgust 1917fevral' 1918. Moscow: Gosudarstvennoe izdatel'stvo.

Seleznev, Fedor Aleksandrovich. 2007. “Konstitutsionnye demokraty i predprinimateli v 1917 g.” Rossiiskaia istoriia 6: 118-30. Semyonov, Alexander. 2009. “The Real and Live Ethnographic Map of Russia”: The Russian Empire in the Mirror of the State Duma." In Empire Speaks out: Languages of Rationalization and Self-Description in the Russian Empire, edited by Ilya Gerasimov, Jan Kusber, and Alexander Semyonov, 191-228. Leiden: Brill.

Smele, Jonathan D. 2015. The 'Russian' Civil Wars, 1916-1926: Ten Years That Shook the World. London: Hurst \& Company. Smith, S. A. 2017. Russia in Revolution: An Empire in Crisis, 1890 to 1928. Oxford: Oxford University Press.

Startsev, Vitalii Ivanovich. 1982. Krakh kerenshchiny. Moscow: Nauka.

Stockdale, Melissa Kirschke. 2016. Mobilizing the Russian Nation: Patriotism and Citizenship in the First World War. Cambridge: Cambridge University Press.

Suny, Ronald Grigor. 1993. The Revenge of the Past: Nationalism, Revolution, and the Collapse of the Soviet Union. Stanford, CA: Stanford University Press.

Swain, Geoffrey. 1996. The Origins of the Russian Civil War. London: Routledge.

Thatcher, Ian D. 2014. “Memoirs of the Russian Provisional Government 1917.” Revolutionary Russia 27 (1): 1-21.

Usmanova, Diliara. 2014. “Oratorika v revoliutsionnom zakonodatel'nom sobranii: Ritoricheskii portret Gosudarstvennoi dumy 1-go i 2-go sozyvov (1906-1907).” Ab Imperio 1: 127-56.

Wade, Rex A. 2017. The Russian Revolution, 1917. 3rd ed. Cambridge: Cambridge University Press.

Wagner, Rudolf G. 2011. "China 'Asleep' and 'Awakening': A Study in Conceptualizing Asymmetry and Coping with It.” Transcultural Studies 2 (1): 4-139.

Zinov'ev, Grigorii Evseevich 1925. God revoliutsii: Fevral' 1917 g. -fevral' 1918 g. Leningrad: Gosudarstvennoe izdatel'stvo.

\section{Archival Sources}

Gosudarstvennyi arkhiv Rossiiskoi Federatsii (GARF).

Gosudarstvennyi tsentral'nyi muzei sovremennoi istorii Rossii (GTsMSIR).

Rossiiskii gosudarstvennyi arkhiv kinofotodokumentov (RGAKFD)

Tsentral'nyi gosudarstvennyi arkhiv kinofotofonodokumentov Sankt-Peterburga (TsGAKFFD SPb).

Cite this article: Sablin, I. 2023. The Democratic Conference and the Pre-Parliament in Russia, 1917: Class, Nationality, and the Building of a Postimperial Community. Nationalities Papers 51: 446-468, doi:10.1017/nps.2021.73 